\title{
Pemodelan Spasial Perubahan Penggunaan Lahan di Taman Nasional Gunung Halimun Salak dan Daerah Penyangganya
}

\section{Spatial Modelling of Land Use Change in Gunung Halimun Salak National Park and Its Buffer Area}

\author{
Iwan Kurniawan $^{1 *}$, Baba Barus ${ }^{2} \&$ Andrea Emma Pravitasari $^{2}$ \\ ${ }^{1}$ Program Studi Ilmu Perencanaan Wilayah, Sekolah Pascasarjana IPB, Jl. Raya Dramaga, Kampus IPB \\ Dramaga, Bogor 16680; ${ }^{2}$ Departemen Ilmu Tanah dan Sumberdaya Lahan, Fakultas Pertanian IPB, Jl. \\ Meranti Kampus IPB Dramaga Bogor 16680; \\ *Penulis korespondensi.e-mail: kurniawankemenhut@gmail.com \\ (Diterima:12 Juni 2017 ; Disetujui: 27 Juli 2017)
}

\begin{abstract}
Land use activities in Gunung Halimun Salak National Park (GHSNP) that does not comply with the zoning plan of GHSNP cause degradation, deforestation and decreasing GHSNP size, while land use activities intensively in the surrounding of GHSNP (buffer area) that does not comply with the spatial allocation plan may alter landscape configuration that influence ecological processes and biodiversity within national park. Predicting land use and land cover (LULC) change patterns in the future provides important information for identifying areas that vulnerable to changes. Multitemporal remote sensing data was used to identify LULC, a multi-layer perceptron neural network with a Markov chain model (MLPNN-M) was used to predict LULC in 2025 and to analyze LULC trend, Overlaying analysis was used to analyze the consistency between LULC and spatial allocation regulation in 2025. The results show that LULC in GHSNP and its buffer area consist of prmary forests, secondary forests, mixture crops, plantations, settlements, agriculture, shrubs, and water. The primary forests, secondary forests, mixture crops, and agriculture were predicted to decrease while settlements, plantations and shrubs were predicted to increase. Land conversion trends into secondary forests, plantations, agriculture and shrubs that begin to show centralized patterns within and the boundaries of GHSNP need to be anticipated. In 2025, inconsistency between land use and GHSNP zonation is the existence of mixture crops, plantations, settlements and agriculture outside the special zone whereas inconsistency between land use and spatial allocation regulation is existence of plantations and agriculture in conservation forest, protection forest and production forest.
\end{abstract}

Keyword: deforestation, multi-layer perceptron neural network, markov chain, land change modeler

\begin{abstract}
ABSTRAK
Kegiatan pemanfaatan lahan di Taman Nasional Gunung Halimun Salak (TNGHS) yang tidak sesuai dengan rencana zonasi TNGHS menyebabkan degradasi, penggundulan hutan dan penurunan luasan TNGHS sedangkan kegiatan pemanfaatan lahan secara intensif di sekitar kawasan TNGHS (daerah penyangga) yang tidak sesuai dengan Rencana Tata Ruang Wilayah (RTRW) dapat mengubah konfigurasi lansekap yang mempengaruhi proses ekologi dan keanekaragaman hayati di dalam taman nasional. Prediksi pola penggunaan/penutupan lahan pada masa depan memberikan informasi penting untuk mengidentifikasi area yang rentan terhadap perubahan. Data penginderaan jarak jauh multi temporal digunakan untuk mengidentifikasi penggunaan/penutupan lahan,
\end{abstract}


Pemodelan multi-layer perceptron neural network dengan Markov chain (MLPNN-M) digunakan untuk memprediksi penggunaan/penutupan lahan pada tahun 2025 dan menganalisis tren penggunaan/penutupan lahan, analisis tumpang susun digunakan untuk menganalisis konsistensi antara penggunaan/penutupan lahan terhadap peraturan alokasi ruang pada tahun 2025. Hasilnya menunjukkan bahwa penggunaan/penutupan lahan di TNGHS dan daerah penyangganya terdiri dari hutan primer, hutan sekunder, kebun campuran, perkebunan, permukiman, pertanian, semak belukar, dan tubuh air. Hutan primer, hutan sekunder, kebun campuran, dan pertanian diprediksi akan mengalami penurunan luasan sedangkan pemukiman, perkebunan dan semak belukar diprediksi akan meningkat. Tren konversi lahan menjadi hutan lahan kering sekunder, perkebunan, pertanian dan semak belukar yang mulai menunjukan pola terpusat di dalam dan batas TNGHS perlu untuk diantisipasi. Pada tahun 2025, akan terjadi inkonsistensi antara penggunaan lahan dan zonasi TNGHS berupa keberadaan kebun campuran, perkebunan, permukiman dan pertanian di luar zona khusus sedangkan inkonsistensi antara penggunaan lahan dan RTRW Kabupaten Bogor berupa keberadaan perkebunan dan pertanian di hutan konservasi, hutan lindung dan hutan produksi.

Kata kunci: deforestasi, multi-layer perceptron neural network, markov chain, pemodelan perubahan penggunaan lahan

\section{PENDAHULUAN}

Taman Nasional Gunung Halimun Salak (TNGHS) sebagai salah satu kawasan pelestarian alam (KPA) pada awalnya ditunjuk sebagai taman nasional pada tahun 1992 melalui Surat Keputusan Menteri Kehutanan nomor 282/Kpts-II/1992 tanggal 28 Pebruari 1992 dengan luas 40,000 hektar sebagai Taman Nasional Gunung Halimun (TNGH) dan resmi ditetapkan pada tanggal 23 Maret 1997 (Balai TNGHS, 2013) dengan batas kawasan seperti tersaji pada Gambar 1. Memperhatikan kondisi hutan sekitar kawasan yang semakin rusak, pada tahun 2003 kawasan Halimun ditambah luasannya dengan memasukkan kawasan hutan Gunung Salak dan Gunung Endut yang status sebelumnya merupakan hutan produksi terbatas dan hutan lindung yang dikelola Perum Perhutani menjadi satu kesatuan hutan konservasi TNGHS melalui Surat Keputusan Menteri Kehutanan nomor 175/Kpts-II/2003 dengan luas total 113,357 hektar pada tanggal 10 Juni 2003 (Balai TNGHS, 2013) dengan batas kawasan seperti tersaji pada Gambar 2.

Tujuan penambahan luasan TNGHS pada tahun 2003 untuk mengendalikan kerusakan hutan belum sepenuhnya berhasil karena ternyata tutupan hutan pada kawasan TNGHS terus mengalami degradasi bahkan deforestasi.
Carolyn et al., (2013) menunjukan bahwa antara tahun 2003 hingga 2011 tutupan hutan TNGHS mengalami degradasi ringan sebesar 6,197.13 hektar dan degradasi berat sebesar 1,200.15 hektar. Ilyas et al., (2014) menyebutkan bahwa antara tahun 2000 hingga 2010 telah terjadi penurunan tutupan hutan (deforestasi) pada kawasan TNGHS sebesar 6,272 hektar.

Akhirnya pada tahun 2016 melalui Surat Keputusan Menteri LHK Nomor 327/ Menlhk/Setjen/PLA.2/4/2016 tanggal 26 April 2016 terjadi perubahan fungsi sebagian kawasan hutan TNGHS seluas 17,373 hektar dan pengembalian areal penggunaan lain (enclave) seluas 7,847 hektar sehingga luas TNGHS berkurang menjadi 87,699 hektar (Balai TNGHS, 2016) dengan batas kawasan seperti tersaji pada Gambar 3. Hakim (2016) menyebutkan bahwa kawasan TNGHS di Kabupaten Lebak yang mengalami perubahan fungsi menjadi hutan produksi dan hutan lindung seluas 9,579.69 hektar ternyata 7,925.31 hektar sudah berupa area dengan tutupan bukan hutan, hanya 1,654.38 hektar yang masih berupa hutan. Hal ini mengindikasikan bahwa perubahan fungsi sebagian kawasan hutan TNGHS dan pengembalian areal penggunaan lain (enclave) merupakan dampak dari terus terkonversinya penutupan hutan sehingga untuk mencegah hal tersebut terus terjadi diperlukan 
upaya antisipasi dan pengendalian. Mascia dan Pailler (2011) menyatakan terdapat tiga bentuk umum kerusakan kawasan lindung yang merupakan sejarah panjang sejak 1900-an, yaitu kerusakan kawasan (downgrading), pengurangan luas (downsizing) dan alih fungsi secara formal (degazettement) kawasan lindung menjadi peruntukan lain.

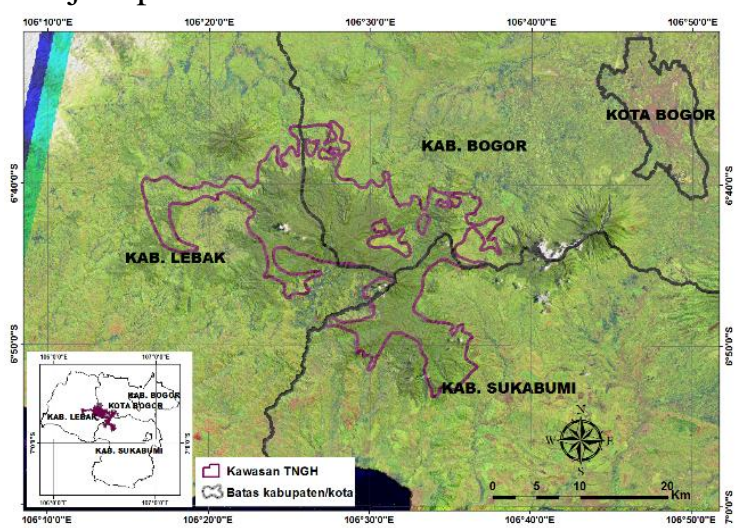

Gambar 1. Batas kawasan TNGHS tahun 1992 pada citra landsat 5 TM liputan tahun 1995

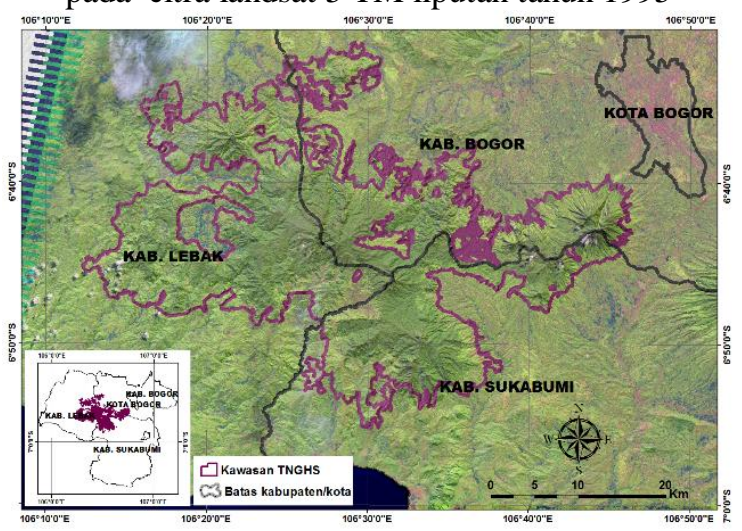

Gambar 2. Batas kawasan TNGHS tahun 2003 pada citra landsat 5 TM liputan tahun 2005

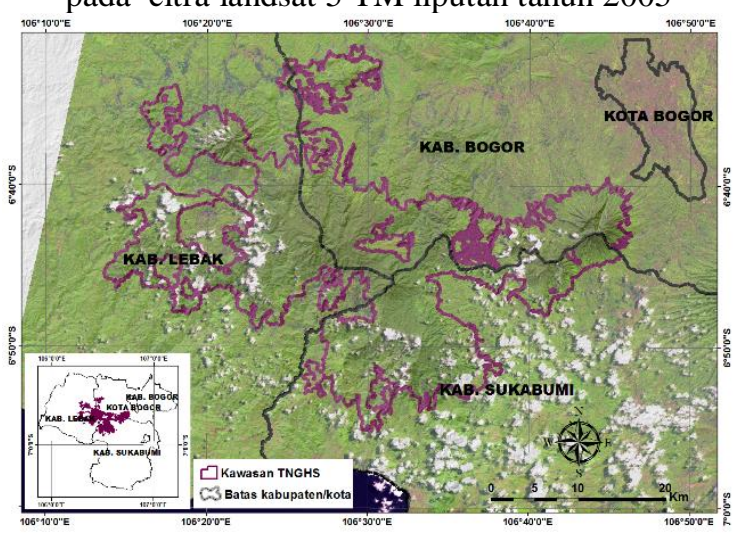

Gambar 3. Batas kawasan TNGHS tahun 2016 pada citra landsat 8 OLI liputan tahun 2015

Taman nasional dan daerah di sekitarnya yang disebut dengan daerah penyangga merupakan satu kesatuan ekosistem yang utuh dan keberadaannya saling mendukung sehingga perubahan penggunaan lahan yang terjadi di daerah penyangga dapat mempengaruhi keberlangsungan fungsi taman nasional dan merugikan masyarakat sekitar hutan maupun di hilirnya. Fungsi taman nasional sebagai pengatur siklus tata air dan pelindung keanekaragaman hayati dapat berjalan dengan baik apabila daerah resapan air, sempadan sungai, kantong-kantong habitat, daerah jelajah satwa, dan koridor habitat satwa yang terdapat di daerah penyangga terjaga kondisi lanskap dan tutupan vegetasinya. (Hansen dan Defries, 2007; Purbawiyatna et al., 2012; Alkaf et al., 2014; Martinuzzi et al., 2015). Oleh karena itu untuk melestarikan dan mendukung fungsi taman nasional, maka pengendalian konversi lahan tidak hanya dilakukan di dalam kawasan tetapi juga pada daerah penyangganya.

Informasi mengenai pola perubahan penggunaan lahan secara spasial dan temporal yang didapatkan dari teknologi penginderaan jauh dapat digunakan untuk menganalisis tren dan faktor-faktor pendorong yang dapat mempengaruhi perubahan penggunaan/ penutupan lahan serta memprediksi perubahan penggunaan lahan di masa yang akan datang melalui pembangunan model spasial sehingga bermanfaat untuk deteksi dini terhadap wilayahwilayah yang rentan akan mengalami konversi lahan yang tidak sesuai dengan peruntukannya. Trimarmanti (2014) menyebutkan bahwa penggunaan lahan yang sesuai dengan peruntukannya dapat menjaga kelestarian lingkungan dan mencegah terjadinya penurunan kualitas lingkungan, sedangkan penggunaan lahan yang tidak sesuai dapat menjadi malapetaka bagi lingkungan dan kehidupan manusia.

Aplikasi Land Change Modeler (LCM) menggunakan metode multi-layer perceptron neural network yang diintegrasikan dengan Markov Chain (MLPNN-M) sangat baik digunakan untuk pemodelan spasial prediksi perubahan pengunaan/penutupan lahan. MLPNN dapat mengintegrasikan berbagai variabel pendorong yang mempengaruhi perubahan pengunaan/penutupan lahan 
sedangkan Markov Chain berfungsi mengontrol dinamika temporal perubahan pengunaan/ penutupan lahan. MLPNN dikenal berfungsi lebih baik dalam pemodelan perubahan pengunaan/penutupan lahan dibandingkan metode regresi logistik karena dapat memodelkan sekaligus sampai dengan sembilan tipe perubahan penggunaan lahan dan semua variabel pendorong yang digunakan tidak harus memiliki hubungan linier serta tidak membutuhkan transformasi variabel pendorong (Khoi dan Murayama, 2010).

Penelitian ini penting dilaksanakan untuk membantu upaya pengendalian pemanfaatan ruang pada kawasan TNGHS dan daerah penyangganya melalui prediksi wilayahwilayah yang rentan mengalami konversi lahan pada tahun 2025 dengan mengambil studi kasus pada kawasan TNGHS di wilayah Kabupaten Bogor dan sepuluh kecamatan penyangganya di Kabupaten Bogor. Berdasarkan informasi wilayah-wilayah yang diprediksi rentan mengalami konversi lahan maka kegiatan pemantauan dan evaluasi pemanfaatan ruang sebagai upaya pengendalian pemanfaatan ruang akan dapat dilaksanakan secara efektif dan efisien. Tahun 2025 dipilih sebagai tahun proyeksi karena berdasarkan Peraturan Daerah Kabupaten Bogor nomor 11 tahun 2016 tentang Rencana Tata Ruang Wilayah (RTRW) Kabupaten Bogor tahun 2016 hingga 2036, kegiatan pemantauan dan evaluasi pemanfaatan ruang akan dilaksanakan pada tahun 2025 .

Berdasarkan latar belakang tersebut maka dirumuskan tujuan penelitian sebagai berikut: (1) menganalisis penggunaan/penutupan lahan pada tahun 2005, 2010 dan 2015; (2) memprediksi penggunaan/penutupan lahan pada tahun 2025; (3) menganalisis tren perubahan penggunaan/penutupan lahan antara tahun 2005 sampai dengan tahun 2025; (4) menganalisis konsistensi penggunaan/penutupan lahan tahun 2025 terhadap zonasi TNGHS dan pola ruang RTRW Kabupaten Bogor.

\section{METODOLOGI}

\section{Lokasi dan waktu penelitian}

Lokasi penelitian terletak pada kawasan TNGHS di wilayah Kabupaten Bogor dan wilayah penyangganya yang berada pada sepuluh kecamatan di Kabupaten Bogor yaitu: Kecamatan Cigombong, Cigudeg, Cijeruk, Jasinga, Leuwiliang, Nanggung, Pamijahan, Sukajaya, Tamansari, dan Tenjolaya. Penelitian berlangsung selama sepuluh bulan mulai Juni 2016 sampai Maret 2017. Peta lokasi penelitian tersaji pada Gambar 4.

\section{Data penelitian}

Data penelitian yang digunakan terdiri dari data primer dan data sekunder. Data primer meliputi: Citra Landsat path 122 row 65 liputan tahun 2005, 2010, dan 2015 yang didownload dari http://www.earthexplorer.usgs.gov; peta kelerengan dan peta ketinggian yang diolah dari data DEM SRTM 30 meter. Data sekunder didapatkan dari beberapa instansi terkait antara lain: peta batas kawasan TNGHS dan peta zonasi TNGHS skala 1:75,000 diperoleh dari Balai TNGHS; peta batas administrasi Kabupaten Bogor dan peta pola ruang Rencana Tata Ruang Wilayah (RTRW) tahun 2016 hingga 2036 skala 1:25,000 diperoleh dari Bappedalitbang Kabupaten Bogor; satuan peta tanah dan peta bentuk lahan skala 1:250,000 didapatkan dari Balai Besar Sumberdaya Lahan Pertanian (BBSDLP); dan data jumlah penduduk didapatkan dari Badan Pusat Statistik (BPS) Kabupaten Bogor.

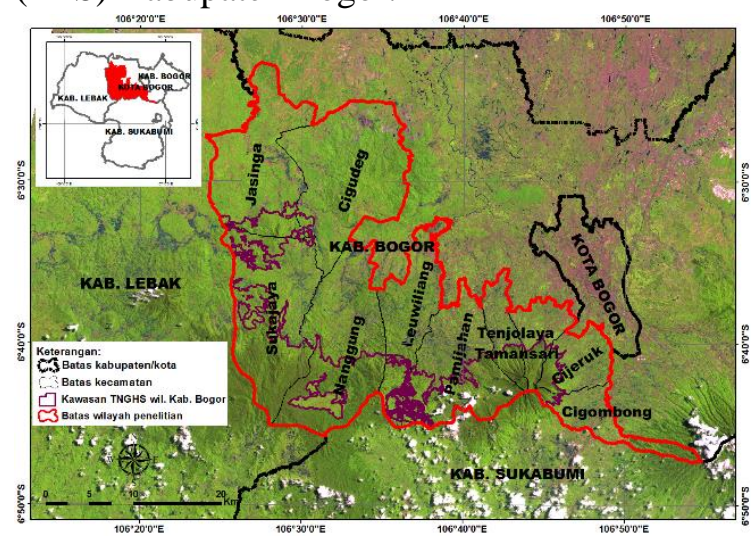

Gambar 4. Lokasi penelitian pada citra landsat 8 OLI liputan tahun 2015 
Analisis data

Analisis penggunaan/penutupan lahan tahun 2005, 2010 dan 2015

Penggunaan/penutupan lahan dianalisis melalui interpretasi citra Landsat $5 \mathrm{TM}$ tahun 2005, Landsat 5 TM tahun 2010 dan Landsat 8 OLI tahun 2015 menggunakan metode interpretasi visual (digitize on screen) pada skala 1:25.000, dengan pendekatan unsur yang meliputi rona, tekstur, pola, ukuran, bentuk, bayangan dan situs (Lillesand dan Kiefer, 1997). Peta penggunaan lahan tahun 2015 yang didapatkan dari Bappedalitbang Kabupaten Bogor juga dijadikan sebagai acuan dalam melakukan interpretasi visual. Klasifikasi penggunaan/penutupan lahan mengacu pada Peraturan Direktur Jenderal Planologi Kehutanan nomor: P.1/VII-IPSDH/2015 tentang Pedoman Pemantauan Penutupan Lahan. Uji hasil interpretasi dilakukan untuk mengetahui akurasi dari interpretasi citra. Pengambilan titik uji dilakukan dengan metode Stratified Random Sampling. Titik uji ditentukan sebanyak 150 titik. Pengujian nilai akurasi diharapkan mendapatkan nilai overall accuracy di atas 85\% (Jensen, 1996). Pengecekan lapangan dan pengecekan melalui citra resolusi tinggi (SPOT 6 tahun 2015, World View tahun 2010 dan Google earth) dilakukan untuk mengetahui kondisi penggunaan lahan pada semua titik uji.

\section{Prediksi penggunaan/penutupan lahan tahun 2025}

Prediksi penggunaan/penutupan lahan tahun 2025 dilakukan menggunakan modul land change modeler (LCM) Idrisi Selva dengan metode pemodelan Multi Layer Perceptron Neural Network (MLPNN) melalui pembangunan dua model untuk menjalankan skema validasi LCM seperti yang dilakukan oleh Saifullah et al., (2017), yaitu: Model 1 untuk memprediksi penggunaan/penutupan lahan tahun 2015 dan Model 2 untuk memprediksi penggunaan/penutupan lahan tahun 2025. Tahapan yang dilakukan dalam prediksi penggunaan/penutupan lahan menggunakan LCM Idrisi adalah sebagai berikut:

1. Menganalisis semua jenis perubahan penggunaan/penutupan lahan yang terjadi antara tahun 2005-2010 (digunakan sebagai variabel dependen dalam Model 1) dan tahun 2010-2015 (digunakan sebagai variabel dependen dalam Model 2).

2. Pemodelan MLPNN untuk membuat peta potensi perubahan penggunaan/penutupan lahan untuk memprediksi penggunaan/penutupan lahan tahun 2015 dan 2025 menggunakan input variabel dependen yang dihasilkan pada tahap pertama dan 15 variabel independen yang mempengaruhi terjadinya perubahan penggunaan/penutupan lahan. Variabel-variabel independen yang digunakan dalam pemodelan MLPNN pada penelitian ini dipilih berdasarkan pengamatan terhadap kondisi wilayah penelitian dan memperhatikan hasil berbagai penelitian tentang faktor-faktor yang mempengaruhi perubahan penggunaan/ penutupan lahan yang telah dilakukan oleh peneliti terdahulu seperti ketinggian, kelerengan, geomorfologi, jarak ke jalan, jarak ke rel kereta api, kepadatan jaringan jalan, jarak ke tubuh air, jarak ke hutan primer, jarak ke hutan sekunder, jarak ke permukiman dan jarak ke lahan pertanian, kepadatan populasi, pertumbuhan populasi (Khoi dan Murayama, 2010; Mozumder dan Tripathi, 2014; Wardani et al., 2016; Prabowo et al., 2017). Variabel independen dapat dipertimbangkan untuk dimasukan ke dalam model apabila memiliki nilai Cramer's V di atas 0.15. Iterasi yang digunakan pada pemodelan MLPNN sebanyak 10,000 untuk mencapai accuracy rate dengan nilai minimal $80 \%$ (Eastman, 2012).

Peta variabel independen yang berhubungan dengan jarak dibangun menggunakan panel distance Idrisi sedangkan peta kepadatan penduduk dibuat dengan asumsi bahwa populasi penduduk menyebar secara sirkuler dengan jari-jari $2 \mathrm{~km}$ dan populasi akan bertambah besar ketika mendekati pusat 
penyebarannya (Alberto et al., 2010). Langkah pertama dibuat peta proporsi populasi menggunakan aplikasi image calculator pada Idrisi dengan rumus :

$P=0.2402 \exp \left(-0.9464 \times\left(\frac{S}{1000}\right)\right)$

Keterangan:

$\mathrm{P}$ : Peta proporsi populasi

$\mathrm{s}$ : peta jarak ke pemukiman

Setelah diperoleh peta proporsi langkah selanjutnya adalah membuat peta kepadatan penduduk dengan menggunakan rumus:

$$
K P=p \times A \times P \times C
$$

Keterangan:

$\rho:$ Kepadatan penduduk non spasial (orang $/ \mathrm{Km}^{2}$ )

A : Luas penyebaran populasi $\left(\mathrm{Km}^{2}\right)$

$=3,14 \times(2 \mathrm{Km})^{2}=12,56$

$\mathrm{P}:$ Peta proporsi populasi

$\mathrm{C}$ : Faktor konversi dari $1 \mathrm{Km}^{2}$ ke 1 Piksel

Membuat matriks probabilitas konversi

lahan untuk memprediksi penggunaan/ penutupan lahan tahun 2015 dan 2025 melalui analisis Markov Chain. Matriks probabilitas konversi menunjukkan besarnya peluang perubahan penggunaan lahan ke penggunaan lainnya dan jumlah piksel suatu penggunaan lahan yang diduga akan berubah menjadi penggunaan lainnya.

Memprediksi penggunaan/penutupan

lahan (hard prediction) dan sensitivitas perubahan lahan (soft prediction) tahun 2015 dan 2025 dengan input peta potensi konversi lahan yang dihasilkan pada tahap kedua serta matriks probabilitas konversi lahan yang dihasilkan pada tahap ketiga.

Validasi pemodelan prediksi penggunaan/ penutupan lahan yang telah dibangun dengan cara membandingkan peta hard prediction tahun 2015 dengan peta penggunan lahan tahun 2015 aktual menggunakan panel validate pada Idrisi Selva (dikategorikan mempunyai akurasi yang baik apabila memiliki nilai Kstandard minimal $0,85)$ dan membandingkan peta soft prediction tahun 2015 dengan peta penggunan lahan tahun 2015 aktual menggunakan panel relative operating characteristic (ROC) pada Idrisi Selva (dikategorikan mempunyai akurasi yang baik apabila memiliki nilai area under the curve (AUC) minimal 0,8) (Eastman, 2012).

\section{Analisis tren perubahan penggunaan/ penutupan lahan tahun 2005-2025}

Peta tren spasial perubahan penggunaan lahan dihasilkan menggunakan panel spatial trend of change pada LCM Idrisi Selva yang mempunyai kemampuan untuk menganalisis suatu set data spasial perubahan penggunaan lahan antara dua titik tahun menjadi suatu pola spasial atau tren sampai dengan sembilan orde/urutan melalui persamaan polinomial. Peta tren spasial perubahan penggunaan lahan yang dihasilkan dilengkapi dengan nilai numerik yang bukan merupakan suatu unit pengukuran tetapi hanya untuk menunjukan lokasi yang terindikasi intensif mengalami perubahan (nilai yang lebih tinggi) atau lokasi dengan perubahan yang kurang intensif (nilai yang lebih rendah) (Eastman, 2012).

\section{Analisis konsistensi penggunaan/penutupan lahan tahun 2025 terhadap zonasi TNGHS dan pola ruang RTRW Kabupaten Bogor}

Analisis konsistensi dilakukan melalui tumpang susun antara peta prediksi penggunaan lahan tahun 2025 dengan peta zonasi kawasan TNGHS revisi tahun 2016 dan peta pola ruang RTRW Kabupaten Bogor tahun 2016 hingga 2036 dengan memperhatikan ketentuan umum penggunaan lahan pada setiap zona dan pola ruang yang diatur dalam regulasi zonasi kawasan TNGHS revisi tahun 2016 dan RTRW Kabupaten Bogor tahun 2016 hingga 2036.

\section{HASIL DAN PEMBAHASAN}

\section{Penggunaan/penutupan lahan tahun 2005, 2010 dan 2015}

Berdasarkan hasil interpretasi citra Landsat tahun 2005, 2010 dan 2015, penggunaan/penutupan lahan pada kawasan TNGHS wilayah Kabupaten Bogor dan sepuluh kecamatan penyangganya terbagi ke dalam delapan kelas yaitu: hutan lahan kering primer (HLKP), hutan lahan kering sekunder (HLKS), kebun campuran (KC), perkebunan (PKB), permukiman (PMK), pertanian (PRT), semak belukar (SB) dan tubuh air (TA) seperti tersaji pada Tabel 2 dan Gambar 5. Berdasarkan 
dokumen rencana pegelolaan TNGHS (BTNGHS, 2013), tipe hutan alam di kawasan TNGHS terdiri dari hutan hujan dataran rendah (100 hingga $1000 \mathrm{mdpl}$ ), hutan hujan pegunungan bawah atau sub montana (1000 hingga $1500 \mathrm{mdpl}$ ), dan hutan hujan pegunungan tengah atau montana (1500 hingga 1929 mdpl).

Hasil uji akurasi interpretasi citra seperti tersaji pada Tabel 1 menunjukkan bahwa hasil interpretasi citra termasuk dalam kategori sangat baik karena memiliki overall accuracy di atas $85 \%$ sehingga dapat digunakan untuk analisis selanjutnya.

Tabel 1. Hasil uji akurasi

\begin{tabular}{llll}
\hline Tahun & $\begin{array}{l}\text { Overall accuracy } \\
(\%)\end{array}$ & $\begin{array}{l}\text { Kappa } \\
(\%)\end{array}$ & accuracy \\
\hline 2005 & 92.67 & 90.50 & \\
2010 & 96.00 & 94.81 & \\
2015 & 96.67 & 95.72 & \\
\hline
\end{tabular}

\section{Prediksi penggunaan/penutupan lahan tahun 2025}

\section{Perubahan penggunaan/penutupan lahan}

Perubahan penggunaan dan penutupan lahan yang terjadi pada periode tahun 2005 hingga 2010 dan periode tahun 2010 hingga 2015 menunjukan pola yang hampir sama seperti ditunjukan pada Tabel 3 dan Tabel 4 yaitu berupa penurunan luasan HLKP dan peningkatan luasan PMK sedangkan SB dan PKB cenderung mengalami peningkatan luasan walaupun juga mengalami penurunan luasan akibat konversi menjadi PMK dan PRT sedangkan HLKS, KC dan PRT cenderung mengalami penurunan luasan karena laju konversinya menjadi penggunaan lain cenderung lebih tinggi dibanding laju penambahan luasannya. Sebaran spasial perubahan penggunaan/penutupan lahan tahun 2005-2015 tersaji pada Gambar 6.

\section{Pemodelan MLPNN}

Hasil pengujian kekuatan pengaruh 15 variabel independen terhadap model seperti disajikan pada Tabel 5 menunjukkan bahwa semua variabel yang dipilih mempunyai nilai Cramer's V di atas 0.15 sehingga memenuhi syarat untuk dimasukan dalam model sesuai yang disarankan Eastman (2012). Metode MLPNN digunakan untuk memodelkan tipe transisi penggunaan lahan di atas 10 hektar. MLPNN hanya mampu memodelkan sembilan tipe transisi penggunaan lahan saja dalam satu sub model sedangkan antara tahun 2005 hingga 2010 (Model 1) terjadi 13 tipe transisi penggunaan lahan sehingga harus dimodelkan ke dalam dua sub model seperti tersaji pada Tabel 6 sedangkan antara tahun 2010 hingga 2015 (Model 2) terjadi 12 tipe transisi penggunaan lahan sehingga juga dimodelkan ke dalam 2 (dua) sub model seperti tersaji pada Tabel 7. Pemodelan MLPNN pada sub model $1.1,1.2,2.1$ dan 2.2 menghasilkan accuracy rate sebesar $97.47 \%, 91.57 \%, 99.14 \%$ dan $90.08 \%$. Nilai accuracy rate hasil pemodelan MLPNN pada keempat sub model menunjukkan nilai yang sangat baik karena mempunyai nilai diatas $80 \%$ seperti yang disarankan oleh Eastman (2012) sehingga memenuhi syarat untuk digunakan membuat peta potensi perubahan penggunaan lahan untuk memprediksi penggunaan lahan tahun 2015 dan 2025 dengan akurat.

Tabel 2. Penggunaan/penutupan lahan tahun 2005, 2010 dan 2015

\begin{tabular}{lllllll}
\hline \multirow{2}{*}{ Penggunaan/penutupan lahan } & \multicolumn{2}{c}{ Tahun 2005} & \multicolumn{2}{c}{ Tahun 2010} & \multicolumn{3}{c}{ Tahun 2015} \\
\cline { 2 - 7 } & ha & $\%$ & ha & $\%$ & ha & $\%$ \\
\hline HLKP & $38,272.40$ & 37.08 & $37,726.82$ & 36.55 & $37,335.77$ & 36.17 \\
HLKS & $22,713.24$ & 22.00 & $22,443.24$ & 21.74 & $21,978.57$ & 21.29 \\
KC & $9,900.33$ & 9.59 & $9,532.42$ & 9.23 & $8,962.36$ & 8.68 \\
PKB & $5,261.39$ & 5.10 & $5,342.93$ & 5.18 & $5,480.81$ & 5.31 \\
PMK & $4,024.52$ & 3.90 & $5,375.06$ & 5.21 & $7,051.21$ & 6.83 \\
PRT & $21,542.43$ & 20.87 & $21,161.74$ & 20.50 & $20,656.21$ & 20.01 \\
SB & 985.50 & 0.95 & $1,117.62$ & 1.08 & $1,234.89$ & 1.20 \\
TA & 527.31 & 0.51 & 527.31 & 0.51 & 527.31 & 0.51 \\
\hline Jumlah & $103,227.12$ & 100.00 & $103,227.12$ & 100.00 & $103,227.12$ & 100.00 \\
\hline
\end{tabular}


Tabel 3. Matriks perubahan penggunaan/penutupan lahan periode tahun 2005-2010

\begin{tabular}{|c|c|c|c|c|c|c|c|c|c|}
\hline \multirow{2}{*}{$\begin{array}{l}\text { Penggunaan/ } \\
\text { penutupan } \\
\text { lahan tahun } \\
2005 \text { (ha) }\end{array}$} & \multicolumn{8}{|c|}{ Penggunaan/penutupan lahan tahun 2010 (ha) } & \multirow{2}{*}{$\begin{array}{l}\text { Jumlah } \\
\text { (ha) }\end{array}$} \\
\hline & HLKP & HLKS & $\mathrm{KC}$ & PKB & PMK & PRT & SB & TA & \\
\hline HLKP & $37,726.82$ & 125.82 & 109.08 & 12.87 & 124.83 & 44.19 & 128.79 & 0.00 & $\begin{array}{l}38,272.4 \\
0\end{array}$ \\
\hline HLKS & 0.00 & $\begin{array}{l}22,317.4 \\
2\end{array}$ & 1.17 & 113.94 & 250.47 & 20.61 & 9.63 & 0.00 & $\begin{array}{l}22,713.2 \\
4\end{array}$ \\
\hline $\mathrm{KC}$ & 0.00 & 0.00 & $9,420.82$ & 0.72 & 443.70 & 35.10 & 0.00 & 0.00 & $9,900.33$ \\
\hline PKB & 0.00 & 0.00 & 0.00 & $5,207.12$ & 53.10 & 1.17 & 0.00 & 0.00 & $5,261.39$ \\
\hline PMK & 0.00 & 0.00 & 0.00 & 0.00 & $\begin{array}{l}4,024.5 \\
2\end{array}$ & 0.00 & 0.00 & 0.00 & $4,024.52$ \\
\hline PRT & 0.00 & 0.00 & 0.00 & 8.28 & 474.12 & $\begin{array}{l}21,060.0 \\
4\end{array}$ & 0.00 & 0.00 & $\begin{array}{l}21,542.4 \\
3\end{array}$ \\
\hline SB & 0.00 & 0.00 & 1.35 & 0.00 & 4.32 & 0.63 & 979.20 & 0.00 & 985.50 \\
\hline TA & 0.00 & 0.00 & 0.00 & 0.00 & 0.00 & 0.00 & 0.00 & $\begin{array}{l}527.3 \\
1\end{array}$ & 527.31 \\
\hline Jumlah (ha) & $37,726.82$ & $\begin{array}{l}22,443.2 \\
4\end{array}$ & $9,532.42$ & $5,342.93$ & $\begin{array}{l}5,375.0 \\
6\end{array}$ & $\begin{array}{l}21,161.7 \\
4\end{array}$ & $\begin{array}{l}1,117.6 \\
2\end{array}$ & $\begin{array}{l}527.3 \\
1\end{array}$ & $\begin{array}{l}103,227 . \\
12\end{array}$ \\
\hline
\end{tabular}

Tabel 4. Matriks perubahan penggunaan/penutupan lahan periode tahun 2010-2015

\begin{tabular}{|c|c|c|c|c|c|c|c|c|c|}
\hline \multirow{2}{*}{$\begin{array}{l}\text { Penggunaan/ } \\
\text { penutupan } \\
\text { lahan tahun } \\
2010 \text { (ha) }\end{array}$} & \multicolumn{8}{|c|}{ Penggunaan/penutupan lahan tahun 2015 (ha) } & \multirow{2}{*}{$\begin{array}{l}\text { Jumlah } \\
\text { (ha) }\end{array}$} \\
\hline & HLKP & HLKS & $\mathrm{KC}$ & PKB & PMK & PRT & SB & TA & \\
\hline HLKP & $37,335.77$ & 39.87 & 0.45 & 1.53 & 169.92 & 55.71 & 123.57 & 0.00 & $37,726.82$ \\
\hline HLKS & 0.00 & $21,938.70$ & 49.68 & 172.26 & 234.36 & 41.85 & 6.39 & 0.00 & $22,443.24$ \\
\hline KC & 0.00 & 0.00 & $8,912.23$ & 8.91 & 563.76 & 45.99 & 1.53 & 0.00 & $9,532.42$ \\
\hline PKB & 0.00 & 0.00 & 0.00 & $5,296.67$ & 43.29 & 2.97 & 0.00 & 0.00 & $5,342.93$ \\
\hline PMK & 0.00 & 0.00 & 0.00 & 0.00 & $5,375.06$ & 0.00 & 0.00 & 0.00 & $5,375.06$ \\
\hline PRT & 0.00 & 0.00 & 0.00 & 1.44 & 654.84 & $20,505.46$ & 0.00 & 0.00 & $21,161.74$ \\
\hline SB & 0.00 & 0.00 & 0.25 & 0.00 & 9.99 & 4.23 & $1,103.40$ & 0.00 & $1,117.87$ \\
\hline TA & 0.00 & 0.00 & 0.00 & 0.00 & 0.00 & 0.00 & 0.00 & 527.31 & 527.31 \\
\hline Jumlah (ha) & $37,335.77$ & $21,978.57$ & $8,962.61$ & $5,480.81$ & $7,051.21$ & $20,656.21$ & $1,234.89$ & 527.31 & $\begin{array}{l}103,227.1 \\
2\end{array}$ \\
\hline
\end{tabular}
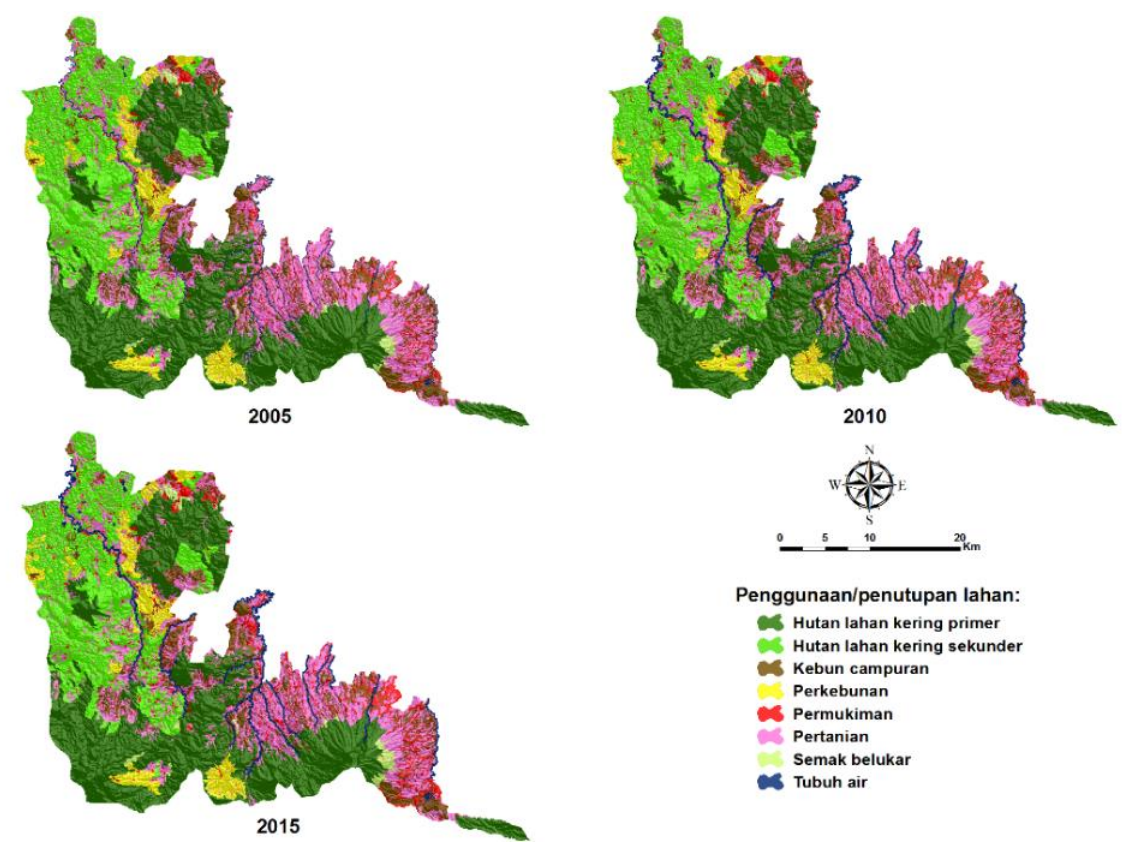

Gambar 5. Penggunaan/penutupan lahan tahun 2005, 2010 dan 2015 


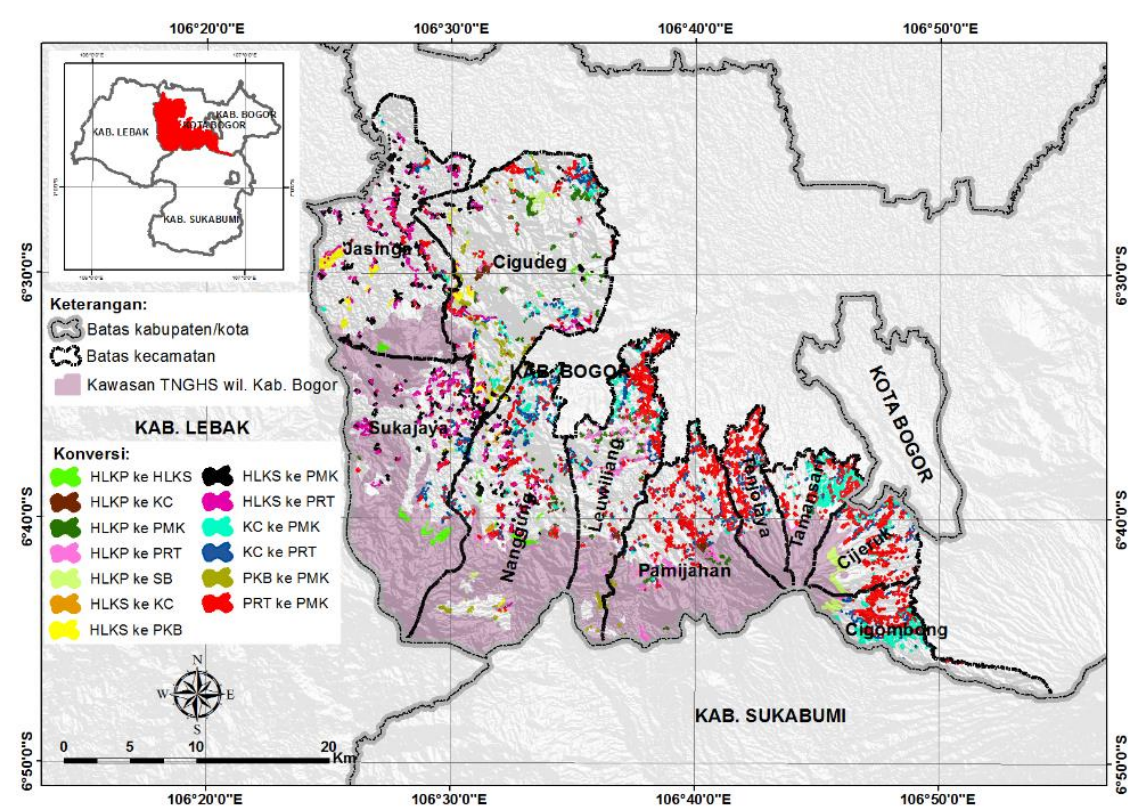

Gambar 6. Sebaran spasial perubahan penggunaan/penutupan lahan antara tahun 2005 sampai dengan 2015

Tabel 5. Pengaruh variabel independen dalam Model 1 dan Model 2

\begin{tabular}{|c|c|c|c|}
\hline Model 1 (prediksi tahun 2015) & Cramer's V & Model 2 (prediksi tahun 2025) & Cramer's V \\
\hline $\begin{array}{l}\text { Tipe penggunaan/penutupan lahan } \\
2010\end{array}$ & 0.6124 & Tipe penggunaan/penutupan lahan 2015 & 0.6124 \\
\hline Bentuk lahan & 0.2655 & Bentuk lahan & 0.2591 \\
\hline Jenis tanah & 0.2958 & Jenis tanah & 0.2904 \\
\hline Ketinggian & 0.2664 & Ketinggian & 0.2658 \\
\hline Kelerengan & 0.2090 & Kelerengan & 0.2103 \\
\hline Kepadatan penduduk tahun 2010 & 0.4183 & Kepadatan penduduk tahun 2015 & 0.4182 \\
\hline Jarak ke sungai & 0.3909 & Jarak ke sungai & 0.3910 \\
\hline Jarak ke jalan & 0.2506 & Jarak ke jalan & 0.2527 \\
\hline Jarak ke HLKP tahun 2010 & 0.3739 & Jarak ke HLKP tahun 2015 & 0.3736 \\
\hline Jarak ke HLKS tahun 2010 & 0.4092 & Jarak ke HLKS tahun 2015 & 0.4104 \\
\hline Jarak ke KC tahun 2010 & 0.4308 & Jarak ke KC tahun 2015 & 0.4280 \\
\hline Jarak ke PKB tahun 2010 & 0.4025 & Jarak ke PKB tahun 2015 & 0.4043 \\
\hline Jarak ke PMK tahun 2010 & 0.4362 & Jarak ke PMK tahun 2015 & 0.4343 \\
\hline Jarak ke PRT tahun 2010 & 0.4243 & Jarak ke PRT tahun 2015 & 0.4228 \\
\hline Jarak ke SB tahun 2010 & 0.3965 & Jarak ke SB tahun 2015 & 0.3960 \\
\hline
\end{tabular}

Tabel 6. Pemodelan MLPNN pada Model 1

\begin{tabular}{clr}
\hline Sub Model & Tipe transisi & Luas transisi (Ha) \\
\hline Sub model 1.1 & HLKP ke HLKS & 125.81 \\
& HLKP ke KC & 109.07 \\
& HLKP ke PKB & 12.86 \\
& HLKP ke PMK & 124.82 \\
& HLKP ke PRT & 44.18 \\
& HLKP ke SB & 128.78 \\
& HLKS ke PKB & 113.93 \\
& HLKS ke PMK & 250.46 \\
Sub model 1.2 & HLKS ke PRT & 20.60 \\
& KC ke PMK & 443.69 \\
& PKB ke PMK & 53.09 \\
& KC ke PRT & 35.09 \\
& PRT ke PMK & 474.11 \\
\hline
\end{tabular}

Tabel 7. Pemodelan MLPNN pada Model 2

\begin{tabular}{clr}
\hline Sub Model & Tipe transisi & Luas transisi (Ha) \\
\hline Sub model 2.1 & HLKP ke HLKS & 39.86 \\
& HLKP ke PMK & 169.91 \\
& HLKP ke PRT & 55.70 \\
& HLKP ke SB & 123.56 \\
& HLKS ke KC & 49.67 \\
& HLKS ke PKB & 172.25 \\
& HLKS ke PMK & 234.35 \\
Sub model 2.2 & HLKS ke PRT & 41.84 \\
& KC ke PMK & 563.75 \\
& KC ke PRT & 45.98 \\
& PKB ke PMK & 43.28 \\
& PRT ke PMK & 654.83 \\
\hline
\end{tabular}




\section{Matriks probabilitas konversi lahan}

Matriks probabilitas konversi lahan hasil analisis Markov Chain seperti tersaji pada Tabel 8 dan Tabel 9 menujukkan bahwa PMK dan TA tidak akan mengalami konversi sedangkan HLKP, HLKS, KC, PKB, PRT dan SB mempunyai peluang akan mengalami konversi menjadi penggunaan lahan lainnya.

Tabel 8. Matriks probabilitas konversi lahan prediksi tahun 2015

\begin{tabular}{ccccccccc}
\hline & HLKP & HLKS & KC & PKB & PMK & PRT & SB & TA \\
\hline HLKP & 0.9827 & 0.0033 & 0.0029 & 0.0003 & 0.0033 & 0.0012 & 0.0034 & 0.0000 \\
HLKS & 0.0000 & 0.9826 & 0.0001 & 0.0050 & 0.0110 & 0.0009 & 0.0004 & 0.0000 \\
KC & 0.0000 & 0.0000 & 0.9516 & 0.0001 & 0.0448 & 0.0035 & 0.0000 & 0.0000 \\
PKB & 0.0000 & 0.0000 & 0.0000 & 0.9897 & 0.0101 & 0.0002 & 0.0000 & 0.0000 \\
PMK & 0.0000 & 0.0000 & 0.0000 & 0.0000 & 1.0000 & 0.0000 & 0.0000 & 0.0000 \\
PRT & 0.0000 & 0.0000 & 0.0000 & 0.0004 & 0.0220 & 0.9776 & 0.0000 & 0.0000 \\
SB & 0.0000 & 0.0000 & 0.0014 & 0.0000 & 0.0044 & 0.0006 & 0.9936 & 0.0000 \\
TA & 0.0000 & 0.0000 & 0.0000 & 0.0000 & 0.0000 & 0.0000 & 0.0000 & 1.0000 \\
\hline
\end{tabular}

Tabel 9. Matriks probabilitas konversi lahan prediksi tahun 2025

\begin{tabular}{lllllllll}
\hline & HLKP & HLKS & KC & PKB & PMK & PRT & SB & TA \\
\hline HLKP & 0.9794 & 0.0021 & 0.0000 & 0.0001 & 0.0090 & 0.0029 & 0.0065 & 0.0000 \\
HLKS & 0.0000 & 0.9555 & 0.0042 & 0.0151 & 0.0209 & 0.0036 & 0.0006 & 0.0000 \\
KC & 0.0000 & 0.0000 & 0.8741 & 0.0018 & 0.1146 & 0.0092 & 0.0003 & 0.0000 \\
PKB & 0.0000 & 0.0000 & 0.0000 & 0.9828 & 0.0162 & 0.0011 & 0.0000 & 0.0000 \\
PMK & 0.0000 & 0.0000 & 0.0000 & 0.0000 & 1.0000 & 0.0000 & 0.0000 & 0.0000 \\
PRT & 0.0000 & 0.0000 & 0.0000 & 0.0001 & 0.0609 & 0.9389 & 0.0000 & 0.0000 \\
SB & 0.0000 & 0.0000 & 0.0014 & 0.0000 & 0.0179 & 0.0074 & 0.9747 & 0.0000 \\
TA & 0.0000 & 0.0000 & 0.0000 & 0.0000 & 0.0000 & 0.0000 & 0.0000 & 1.0000 \\
\hline
\end{tabular}

Prediksi penggunaan/penutupan lahan (hard prediction) dan sensitivitas perubahan lahan (soft prediction)

Peta potensi perubahan penggunaan lahan hasil pemodelan MLPNN dan matriks probabilitas konversi lahan hasil analisis Markov Chain kemudian digunakan untuk menghasilkan peta prediksi penggunaan lahan (hard prediction) tahun 2015 dan 2025 seperti tersaji pada Gambar 7 serta peta prediksi sensitivitas perubahan lahan (soft prediction) tahun 2015 dan 2025 seperti tersaji pada Gambar 8 dan Gambar 9. Memperhatikan luasan masingmasing kelas seperti tersaji pada Tabel 10 dan matriks perubahan yang tersaji pada Tabel 11, diprediksi bahwa selama kurun waktu 20152025 akan terjadi penurunan luasan HLKP dan peningkatan luasan PMK dan SB sedangkan PKB cenderung mengalami peningkatan luasan walaupun juga mengalami sedikit penurunan luasan akibat konversi menjadi PMK dan PRT sedangkan HLKS, KC dan PRT cenderung mengalami penurunan luasan karena laju konversinya menjadi penggunaan lain cenderung lebih tinggi dibanding laju penambahan luasannya. Sebaran spasial perubahan penggunaan/penutupan lahan antara tahun 2015 hingga 2025 tersaji pada Gambar 10.

Wilayah-wilayah yang sensitif akan mengalami konversi tersebar pada batas-batas terluar kawasan TNGHS, batas kawasan hutan lindung, batas kawasan hutan produksi, lahan pertanian, kebun campuran serta areal hak guna usaha (HGU) yang masih berupa hutan lahan kering sekunder. Konversi lahan pertanian dan kebun campuran apabila memperhatikan Tabel 11 secara umum diprediksi sensitif untuk terkonversi menjadi permukiman sedangkan perubahan hutan lahan kering sekunder yang berada di dalam kawasan HGU merupakan upaya pembukaan lahan dalam rangka persiapan lahan untuk penanaman. 

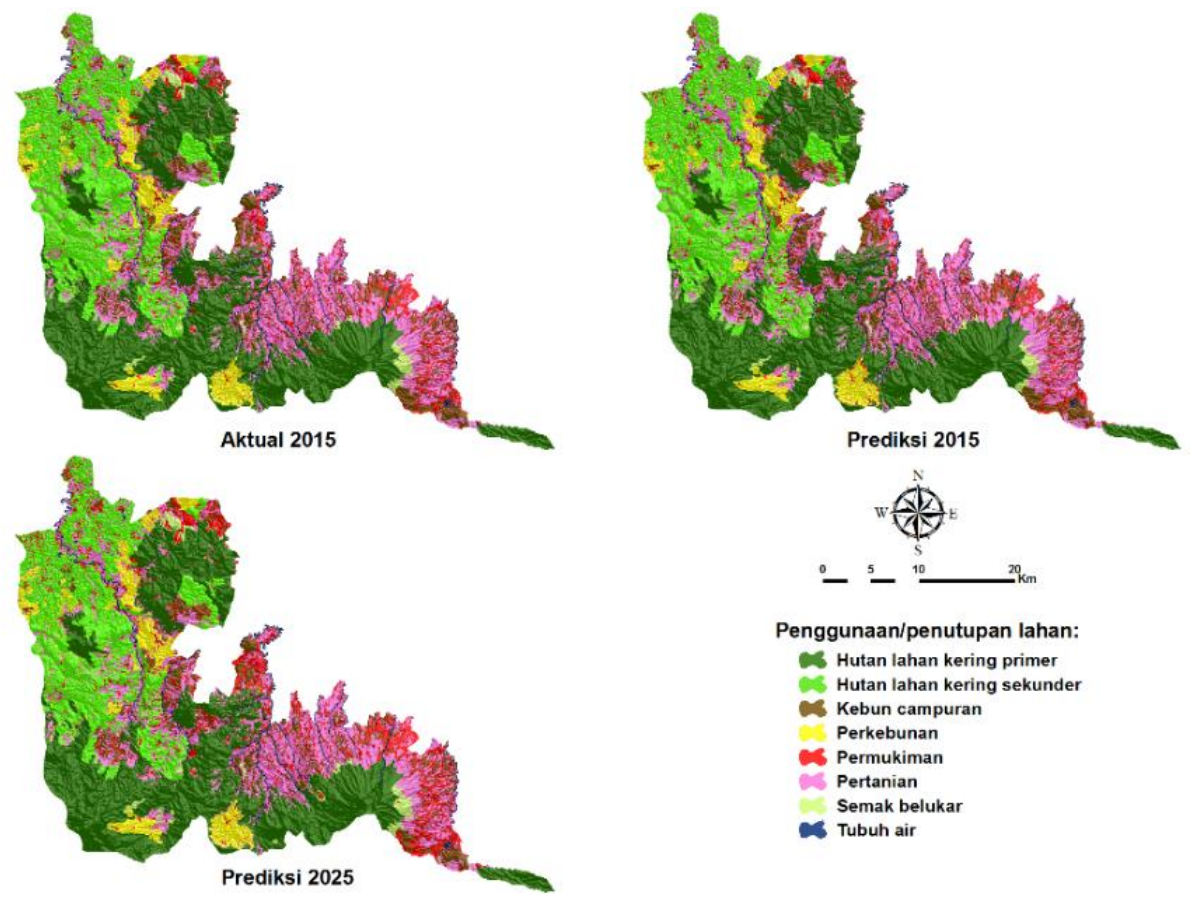

Gambar 7. Peta penggunaan lahan tahun 2015 aktual, prediksi tahun 2015 dan prediksi tahun 2025

Tabel 10. Penggunaan/penutupan lahan tahun 2015 aktual dan prediksi tahun 2025

\begin{tabular}{lllllll}
\hline \multirow{2}{*}{ Penggunaan/penutupan lahan } & \multicolumn{2}{l}{ Tahun 2015 (aktual) } & \multicolumn{2}{l}{$\begin{array}{l}\text { Tahun } \\
\text { (prediksi) }\end{array}$} & & \multicolumn{2}{c}{ Penambahan/pengurangan } \\
\cline { 2 - 7 } & ha & $\%$ & ha & $\%$ & ha & $\%$ \\
\hline HLKP & $37,335.77$ & 36.17 & $36,570.06$ & 35.43 & -765.72 & -2.05 \\
HLKS & $21,978.57$ & 21.29 & $21,091.36$ & 20.43 & -887.22 & -4.04 \\
KC & $8,962.36$ & 8.68 & $7,946.08$ & 7.70 & $-1,016.28$ & -11.34 \\
PKB & $5,480.81$ & 5.31 & $5,724.44$ & 5.55 & 243.63 & 4.45 \\
PMK & $7,051.21$ & 6.83 & $10,222.62$ & 9.90 & $3,171.41$ & 44.98 \\
PRT & $20,656.21$ & 20.01 & $19,668.64$ & 19.05 & -987.57 & -4.78 \\
SB & $1,234.89$ & 1.20 & $1,476.63$ & 1.43 & 241.74 & 19.58 \\
TA & 527.31 & 0.51 & 527.31 & 0.51 & 0.00 & 0.00 \\
\hline Jumlah & $103,227.12$ & 100.00 & $103,227.12$ & 100.00 & & \\
\hline
\end{tabular}
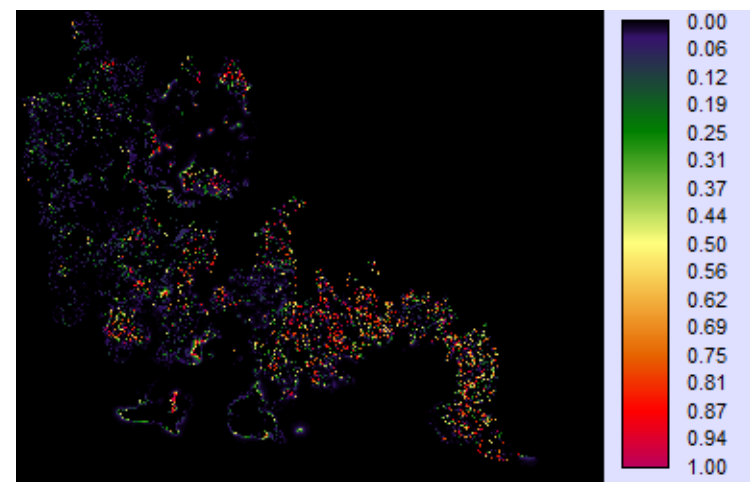

Gambar 8. Peta prediksi sensitivitas perubahan lahan tahun 2015

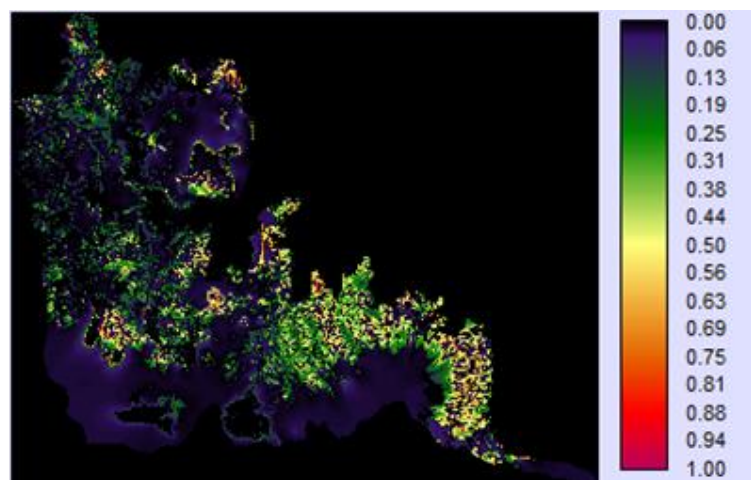

Gambar 9. Peta prediksi sensitivitas perubahan lahan tahun 2025 


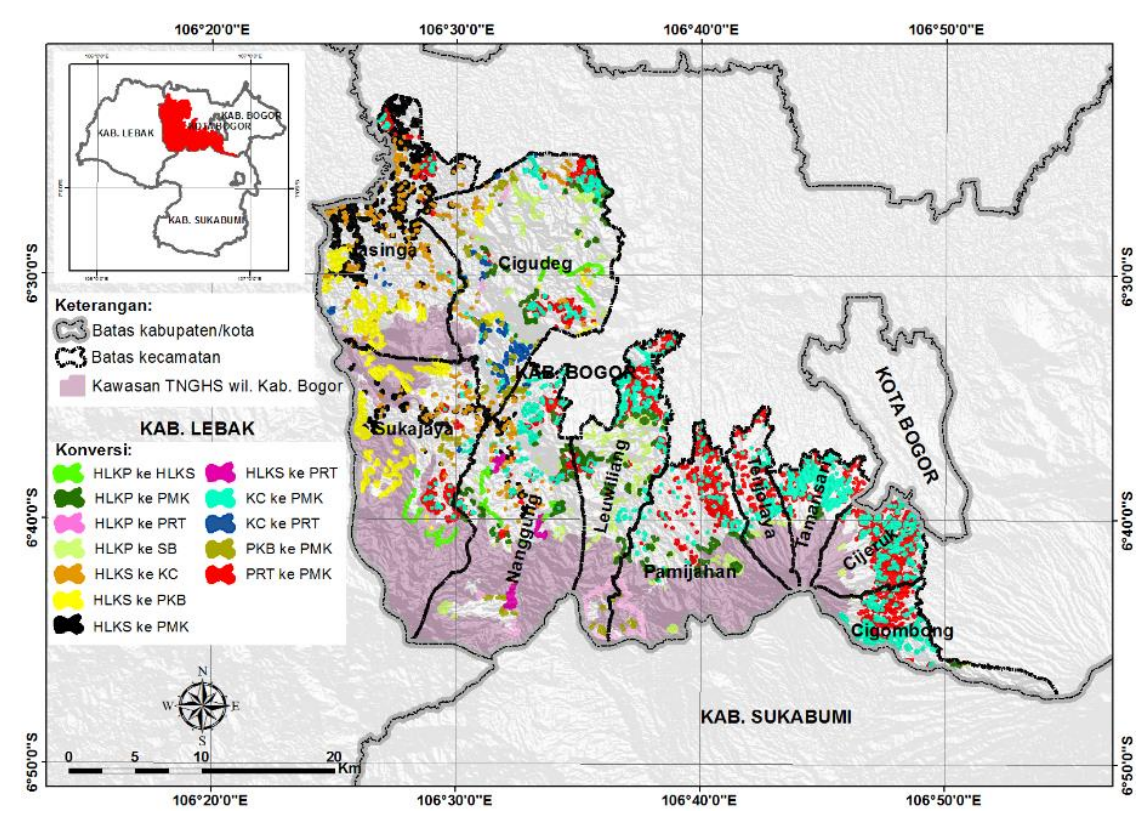

Gambar 10. Sebaran spasial prediksi perubahan penggunaan/penutupan lahan antara tahun 2015 sampai dengan 2025

Tabel 11. Matriks perubahan penggunaan/penutupan lahan periode tahun 2015-2025

\begin{tabular}{|c|c|c|c|c|c|c|c|c|c|}
\hline \multirow{2}{*}{$\begin{array}{l}\text { Penggunaan/ } \\
\text { penutupan } \\
\text { lahan tahun } \\
2015 \text { (ha) }\end{array}$} & \multicolumn{8}{|c|}{ Penggunaan/penutupan lahan tahun 2025 (ha) } & \multirow{2}{*}{$\begin{array}{l}\text { Jumlah } \\
\text { (ha) }\end{array}$} \\
\hline & HLKP & HLKS & $\mathrm{KC}$ & PKB & PMK & PRT & SB & TA & \\
\hline HLKP & $\begin{array}{l}36,570.0 \\
6\end{array}$ & 77.58 & 0.00 & 0.00 & 337.86 & 108.54 & 241.74 & 0.00 & $\begin{array}{l}37,335.7 \\
7\end{array}$ \\
\hline HLKS & 0.00 & $\begin{array}{l}21,013.7 \\
8\end{array}$ & 93.06 & 332.19 & 459.45 & 80.10 & 0.00 & 0.00 & $\begin{array}{l}21,978.5 \\
7\end{array}$ \\
\hline $\mathrm{KC}$ & 0.00 & 0.00 & $\begin{array}{l}7,853 . \\
02\end{array}$ & 0.00 & $1,026.99$ & 82.35 & 0.00 & 0.00 & $8,962.36$ \\
\hline PKB & 0.00 & 0.00 & 0.00 & $\begin{array}{l}5,392 . \\
25\end{array}$ & 88.56 & 0.00 & 0.00 & 0.00 & $5,480.81$ \\
\hline PMK & 0.00 & 0.00 & 0.00 & 0.00 & $7,051.21$ & 0.00 & 0.00 & 0.00 & $7,051.21$ \\
\hline PRT & 0.00 & 0.00 & 0.00 & 0.00 & $1,258.56$ & $\begin{array}{l}19,397.6 \\
5\end{array}$ & 0.00 & 0.00 & $\begin{array}{l}20,656.2 \\
1\end{array}$ \\
\hline SB & 0.00 & 0.00 & 0.00 & 0.00 & 0.00 & 0.00 & $\begin{array}{l}1,234 . \\
89\end{array}$ & 0.00 & $1,234.89$ \\
\hline TA & 0.00 & 0.00 & 0.00 & 0.00 & 0.00 & 0.00 & 0.00 & $\begin{array}{l}527.3 \\
1\end{array}$ & 527.31 \\
\hline Jumlah (ha) & $\begin{array}{l}36,570.0 \\
6\end{array}$ & $\begin{array}{l}21,091.3 \\
6\end{array}$ & $\begin{array}{l}7,946 . \\
08 \\
\end{array}$ & $\begin{array}{l}5,724 . \\
44 \\
\end{array}$ & $\begin{array}{l}10,222.6 \\
2\end{array}$ & $\begin{array}{l}19,668.6 \\
4\end{array}$ & $\begin{array}{l}1,476 . \\
63 \\
\end{array}$ & $\begin{array}{l}527.3 \\
1 \\
\end{array}$ & $\begin{array}{l}103,227 . \\
12\end{array}$ \\
\hline
\end{tabular}

\section{Validasi model}

Hasil validasi model menghasilkan nilai Kstandard sebesar 0.9761 dan nilai area under curve (AUC) sebesar 0.939 yang menunjukkan bahwa model telah memenuhi syarat dan memiliki kesesuaian spasial yang sangat baik dalam memprediksi perubahan penggunaan lahan dan memprediksi sensitivitas perubahan penggunaan lahan.

\section{Tren perubahan penggunaan/penutupan lahan antara tahun 2005 hingga 2025}

Hasil analisis tren spasial perubahan penggunaan lahan pada orde ke-9 seperti tersaji pada Gambar 11 menunjukan bahwa antara 
tahun 2005 hingga 2015 tren perubahan penggunaan/penutupan lahan menjadi HLKS, PKB, dan SB menunjukan pola sebaran cenderung terpusat sedangkan tren perubahan penggunaan/penutupan lahan menjadi $\mathrm{KC}$, PMK dan PRT menunjukan pola sebaran acak. Antara periode tahun 2015 hingga 2025 tren perubahan penggunaan/penutupan lahan mulai mengalami pergeseran. Tren perubahan penggunaan/penutupan lahan menjadi HLKS yang semula hanya terpusat di Kecamatan Sukajaya dan Nanggung mulai meluas sampai ke Kecamatan Cigudeg; tren perubahan penggunaan/penutupan lahan menjadi $\mathrm{KC}$ yang semula menunjukan pola sebaran acak mulai menunjukan tren terpusat di Kecamatan Jasinga; tren perubahan penggunaan/penutupan lahan menjadi PKB masih menunjukan pola sebaran terpusat tetapi mengalami tren perluasan dari yang sebelumnya hanya terpusat di Kecamatan Jasinga mulai meluas sampai ke Kecamatan Sukajaya; tren perubahan penggunaan/ penutupan lahan menjadi PMK yang sebelumnya menunjukan pola sebaran acak mulai menunjukan pemusatan di Kecamatan Tamansari, Cijeruk, Cigombong, Nanggung dan Jasinga; tren perubahan penggunaan/penutupan lahan menjadi PRT yang sebelumnya menunjukan pola sebaran acak mulai menunjukan pemusatan di Kecamatan Nanggung, Leuwiliang, Pamijahan dan Cigudeg; tren perubahan penggunaan/ penutupan lahan menjadi SB yang sebelumnya menunjukan pola sebaran terpusat di Kecamatan Tenjolaya, Tamansari, Cijeruk dan Cigombong mulai menunjukan pergeseran ke Kecamatan Pamijahan, Nanggung dan Cigudeg

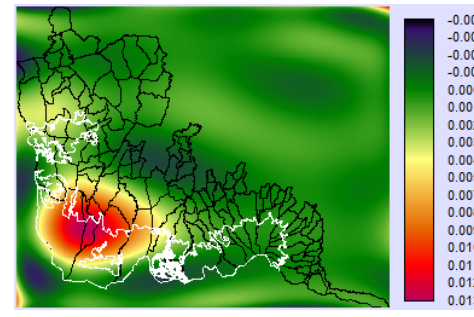

Tren konversi menjadi HLKS (2005-2015)

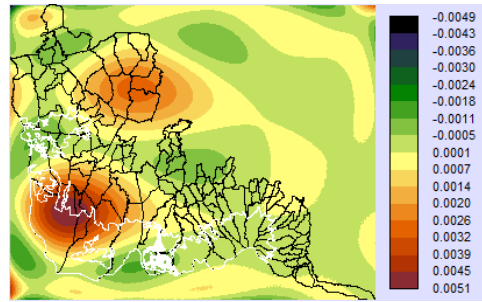

Tren konversi menjadi HLKS (2015-2025)

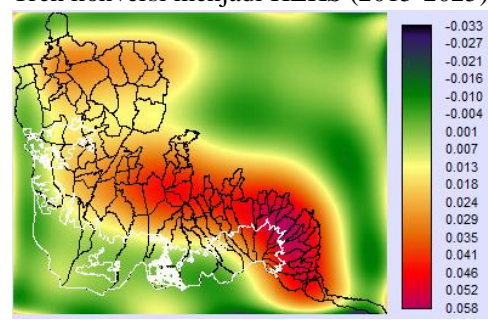

Tren konversi menjadi PMK (2005-2015)

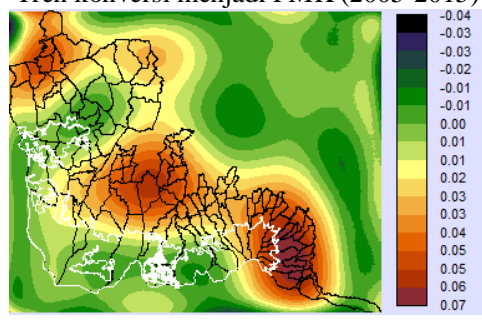

Tren konversi menjadi PMK (2015-2025)

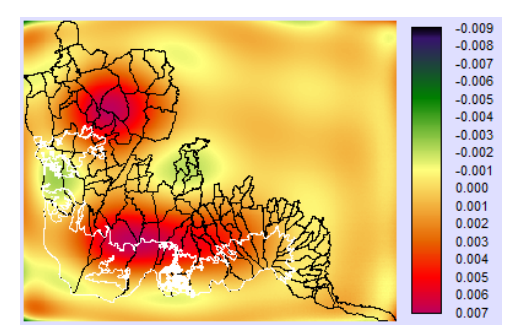

Tren konversi menjadi KC (2005-2015)

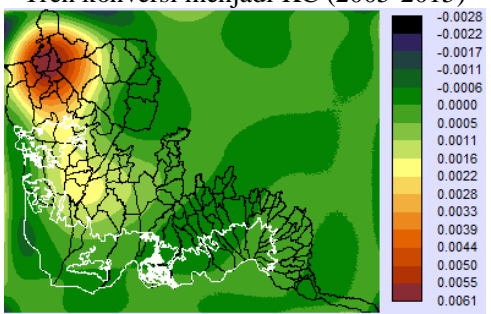

Tren konversi menjadi KC (2015-2025)

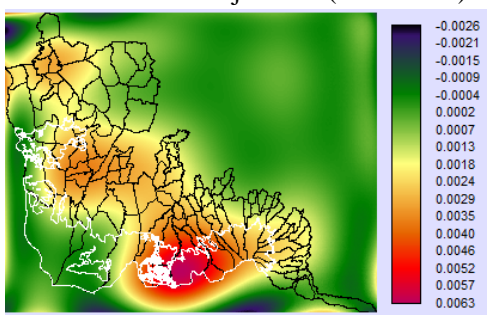

Tren konversi menjadi PRT (2005-2015)

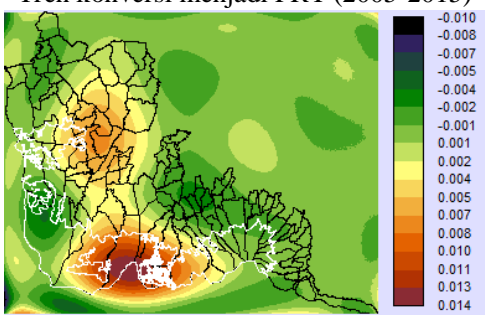

Tren konversi menjadi PRT (2015-2025)

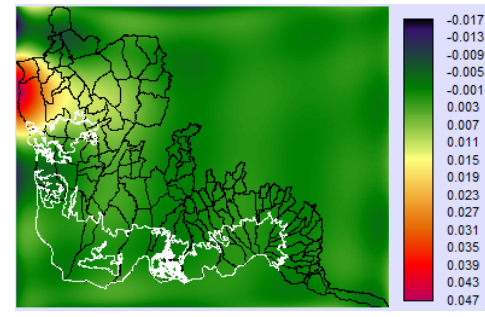

Tren konversi menjadi PKB (2005-2015)

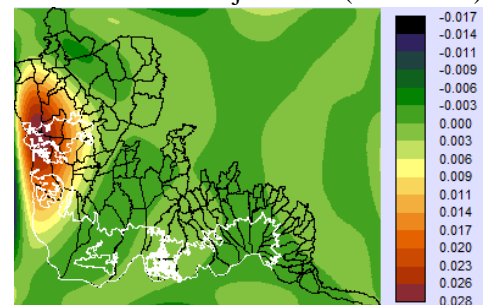

Tren konversi menjadi PKB (2015-2025)

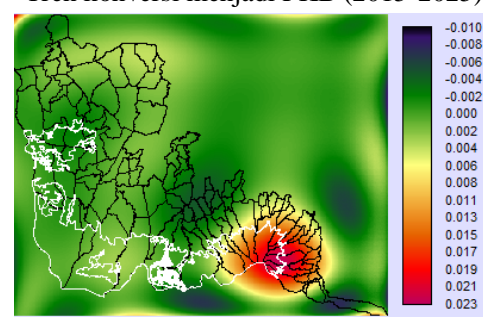

Tren konversi menjadi SB (2005-2015)

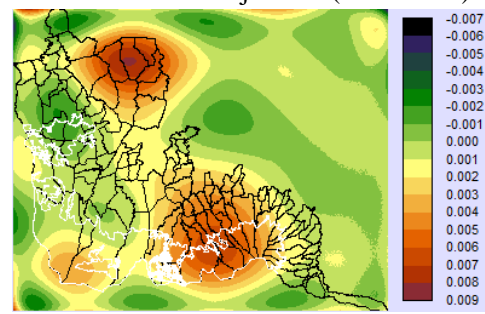

Tren konversi menjadi SB (2015-2025)

Gambar 11. Tren perubahan penggunaan/penutupan lahan antara tahun 2005 hingga 2025

Keterangan: polygon hitam menunjukan batas administrasi desa, polygon putih menunjukan batas kawasan TNGHS 
Tren perubahan penggunaan/penutupan lahan antara tahun 2015 hingga 2025 yang perlu diwaspadai karena cenderung mengancam keberadaan kawasan TNGHS adalah tren perubahan penggunaan/penutupan lahan menjadi HLKS di Kecamatan Sukajaya dan Nanggung; tren perubahan penggunaan/ penutupan lahan menjadi PKB di Kecamatan Jasinga dan Sukajaya; tren perubahan penggunaan/penutupan lahan menjadi PRT di Kecamatan Nanggung, Leuwiliang, dan Pamijahan; serta tren perubahan penggunaan/ penutupan lahan menjadi SB di Kecamatan Nanggung dan Pamijahan.

\section{Konsistensi penggunaan/penutupan lahan tahun 2025 terhadap zonasi TNGHS dan pola ruang RTRW Kabupaten Bogor}

Zonasi kawasan TNGHS revisi tahun 2016 di wilayah Kabupaten Bogor terdiri dari zona inti (ZI), zona rimba (ZR), zona rehabilitasi (ZRhb), zona tradisional (ZT), zona pemanfaatan (ZP), zona khusus (ZK) dan zona budaya (ZB) sedangkan pola ruang RTRW Kabupaten Bogor tahun 2016 hingga 2036 pada wilayah penelitian terdiri dari enclave kawasan hutan (EH), kawasan hutan konservasi (HK), kawaan hutan lindung (HL), kawasan hutan produksi terbatas (HPT), kawasan hutan produksi tetap (HP), kawasan permukiman perkotaan kepadatan tinggi (Pp1), kawasan permukiman perkotaan kepadatan sedang (Pp2), kawasan permukiman perkotaan kepadatan rendah (Pp3), kawasan peruntukan industri (KPI), kawasan peruntukan lahan basah (LB), kawasan peruntukan lahan kering (LK), kawasan peruntukan perkebunan dan tanaman tahunan (PB), kawasan peruntukan permukiman perdesaan (PD), dan situ.

Berdasarkan analisis tumpang susun dan memperhatikan ketentuan umum regulasi peruntukan ruang, penggunaan lahan tahun 2025 yang akan mengalami inkonsistensi dengan zonasi TNGHS dan pola ruang RTRW Kabupaten Bogor nampak tersebar seperti disajikan pada Gambar 12 dengan tipe dan luas inkonsistensi disajikan pada Tabel 12 dan Tabel 13.

Tabel 12. Inkonsistensi penggunaan lahan tahun 2025 (>10 Ha) terhadap zonasi TNGHS

\begin{tabular}{llll}
\hline Kesesuaian & $\begin{array}{l}\text { Penggunaan } \\
\text { lahan 2025 }\end{array}$ & Zona & $\begin{array}{l}\text { Luas } \\
\text { (Ha) }\end{array}$ \\
\hline tidak sesuai & PKB & ZR & 46,77 \\
tidak sesuai & PRT & ZR & 145,54 \\
tidak sesuai & KC & ZRhb & 61,85 \\
tidak sesuai & PKB & ZRhb & 54,87 \\
tidak sesuai & PRT & ZRhb & 316,57 \\
tidak sesuai & PKB & ZT & 23,43 \\
tidak sesuai & PRT & ZT & 16,03 \\
tidak sesuai & PMK & ZP & 11,23 \\
tidak sesuai & PRT & ZP & 161,61 \\
\hline
\end{tabular}

Tabel 13. Inkonsistensi penggunaan lahan tahun 2025 (>100 Ha) terhadap pola ruang RTRW Kabupaten Bogor

\begin{tabular}{llll}
\hline Kesesuaian & $\begin{array}{l}\text { Penggunaan } \\
\text { lahan 2025 }\end{array}$ & $\begin{array}{l}\text { Pola } \\
\text { ruang }\end{array}$ & $\begin{array}{l}\text { Luas } \\
\text { (Ha) }\end{array}$ \\
\hline Sesuai bersyarat & PMK & LK & 418,19 \\
Sesuai bersyarat & PMK & LB & 1271,43 \\
Sesuai bersyarat & PMK & PB & 1422,58 \\
Sesuai bersyarat & PRT & PB & 3934,29 \\
tidak sesuai & PKB & HK & 517,13 \\
tidak sesuai & PRT & HP & 166,96 \\
tidak sesuai & PRT & HK & 773,08 \\
tidak sesuai & PRT & HL & 229,73 \\
\hline
\end{tabular}



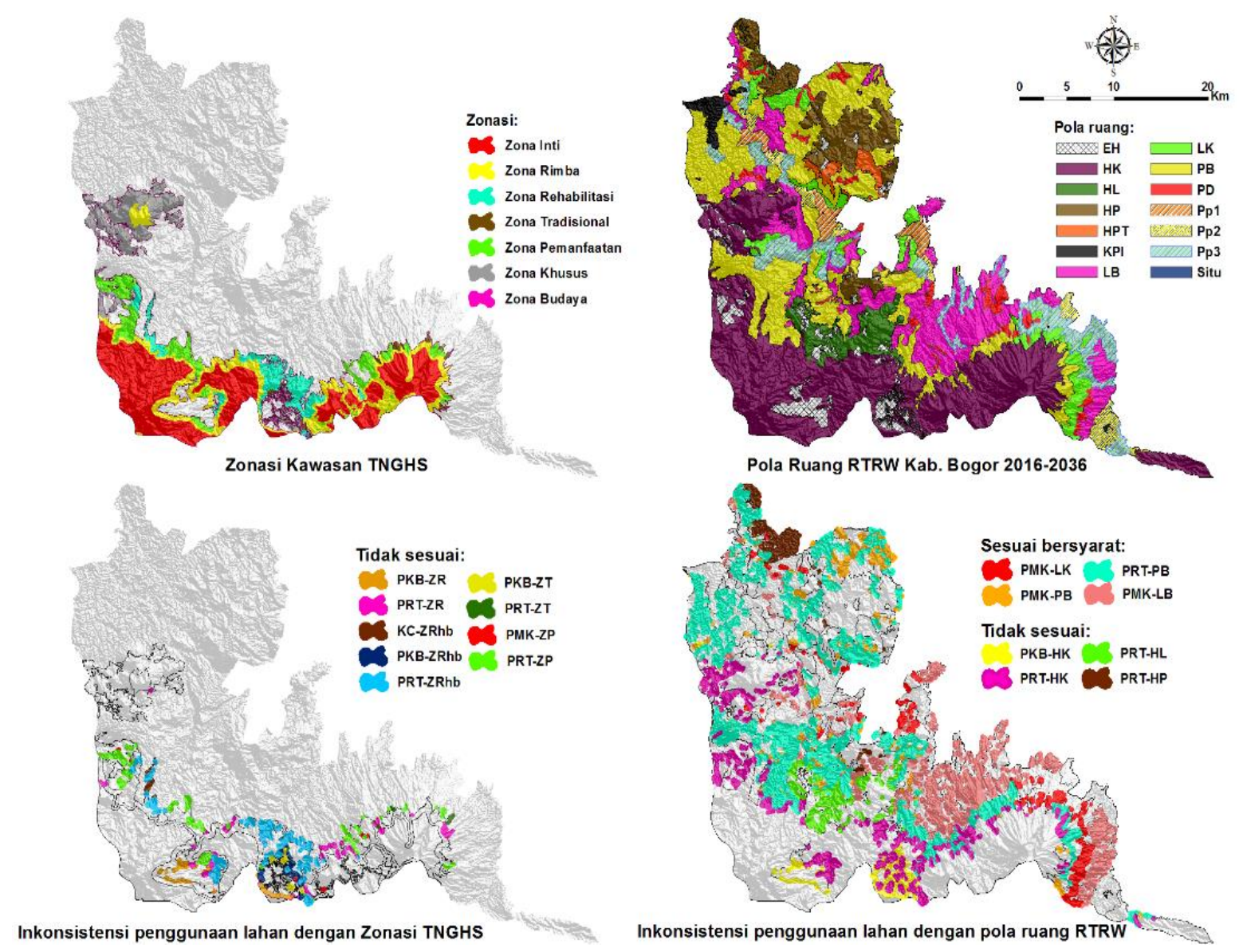

Gambar 12. Sebaran wilayah yang diprediksi akan mengalami inkonsitensi penggunaan lahan dengan zonasi TNGHS dan pola ruang RTRW Kab. Bogor pada tahun 2025

Sumber: Balai TNGHS (2016), Bappedalitbang Kabupaten Bogor (2016) dan hasil pengolahan

\section{KESIMPULAN DAN REKOMENDASI}

\section{Kesimpulan}

1. Penggunaan/penutupan lahan pada kawasan TNGHS di wilayah Kabupaten Bogor dan kecamatan penyangganya berupa hutan lahan kering primer (HLKP), hutan lahan kering sekunder (HLKS), kebun campuran (KC), perkebunan (PKB), permukiman (PMK), pertanian (PRT), semak belukar (SB), dan tubuh air (TA).

2. Selama kurun waktu 2015 hingga 2025 diprediksi akan terjadi penurunan luasan HLKP, HLKS, KC dan PRT sedangkan luasan PKB, PMK dan SB akan mengalami peningkatan.

3. Tren perubahan penggunaan/penutupan lahan antara tahun 2015 hingga 2025 yang perlu diwaspadai karena cenderung mengancam keberadaan kawasan TNGHS adalah tren konversi lahan menjadi HLKS di
Kecamatan Sukajaya dan Nanggung; tren konversi lahan menjadi PKB di Kecamatan Jasinga dan Sukajaya; tren konversi lahan menjadi PRT di Kecamatan Nanggung, Leuwiliang, dan Pamijahan; serta tren konversi lahan menjadi SB di Kecamatan Nanggung dan Pamijahan.

4. Penggunaan lahan tahun 2025 (>10 Ha) yang diprediksi akan tidak sesuai dengan zonasi TNGHS berupa PKB dan PRT di ZR; KC, PKB dan PRT di ZRhb; PKB dan PRT di ZT; serta PMK dan PRT di ZP sedangkan penggunaan lahan tahun 2025 (> $100 \mathrm{Ha}$ ) yang diprediksi akan tidak sesuai dengan pola ruang RTRW Kabupaten Bogor berupa PKB di HK, PRT di HK, PRT di HL dan PRT di HP sedangkan yang masuk kategori sesuai bersyarat berupa PMK di LB, PMK di LK, PMK di PB dan PRT di PB. 


\section{Rekomendasi}

Peraturan daerah Kabupaten Bogor nomor 11 tahun 2016 tentang RTRW Kabupaten Bogor 2016 hingga 2036 telah mengatur pola ruang sebagian besar wilayah yang berbatasan dengan kawasan TNGHS untuk diperuntukan sebagai kawasan peruntukan perkebunan dan tanaman tahunan yang merupakan bentuk yang baik sebagai penyangga (buffer) kawasan TNGHS, tetapi ternyata penggunaan lahan aktualnya sebagian besar masih banyak yang berupa lahan pertanian dalam bentuk sawah atau tegalan padahal wilayah ini termasuk kawasan yang rawan bencana dan wilayah yang berperan penting sebagai daerah resapan air sehingga untuk mencegah terjadinya bencana dan mengurangi tekanan terhadap kawasan TNGHS sebaiknya segera diarahkan untuk dikembalikan sesuai peruntukannya sebagai kawasan perkebunan dan tanaman tahunan dengan kegiatan budi daya komoditas perkebunan atau tanaman tahunan yang dapat meningkatkan kesejahteraan masyarakat.

Beberapa wilayah yang berbatasan dengan kawasan TNGHS yang dalam pola ruang justru diperuntukan sebagai kawasan pertanian lahan basah dan lahan kering sebaiknya dapat ditinjau kembali mengingat kecenderungan besarnya peluang perluasan lahan pertanian sampai ke dalam kawasan TNGHS bahkan perubahan menjadi lahan non pertanian seperti permukiman yang dapat menimbulkan tekanan bahkan ancaman degradasi dan deforestasi kawasan TNGHS.

\section{UCAPAN TERIMA KASIH}

Apresiasi dan ungkapan rasa terima kasih yang sebesar-besarnya disampaikan kepada Pusat Pembinaan Pendidikan dan Pelatihan Perencanaan (Pusbindiklatren) Bappenas RI selaku pemberi sponsor kegiatan karyasiswa Tahun 2015, Bapedalitbang Kabupaten Bogor dan Balai TNGHS serta berbagai instansi dan pihak yang membantu dalam pengumpulan data penelitian.

\section{DAFTAR PUSTAKA}

Alberto, A., \& Dasanto, B. D. (2010). Model Perubahan Penggunaan Lahan dan Pendugaan Cadangan Karbon di Daerah Aliran Sungai Cisadane, Jawa Barat. Jurnal Agromet Indonesia, 24(2), 18-26.

Alkaf, M., Munibah, K., \& Rusdiana, O. (2014). Model Spasial Perubahan Penggunaan Lahan di Taman Nasional Gunung Merbabu dan Daerah Penyangganya. Majalah Ilmiah Globe, 16(1), 43-50.

Badan Perencanaan Pembangunan Daerah Kabupaten Bogor. (2016). Rencana Tata Ruang Wilayah Kabupaten Bogor Tahun 2016-2036.

Balai Taman Nasional Gunung Halimun Salak. (2013). Rencana Pengelolaan Taman Nasional Gunung Halimun Salak periode 2014-2023.

Balai Taman Nasional Gunung Halimun Salak. (2016). Penataan Zonasi Taman Nasional Gunung Halimun Salak Revisi I.

Carolyn, R. D., Baskoro, D. P. T., \& Prasetyo, L. B. (2013). Analisis Degradasi untuk Penyusunan Arahan Strategi Pengendaliannya di Taman Nasional Gunung Halimun Salak Provinsi Jawa Barat. Majalah Ilmiah Globe 15(1), 3947.

Direktorat Jenderal Planologi Kehutanan. (2015). Peraturan Direktur Jenderal Planologi Kehutanan Nomor: P.1/VIIIPSDH/2015 tentang Pedoman Pemantauan Penutupan Lahan.

Eastman, J. R. (2012). Idrisi Selva Manual, Manual Version 17.01. Clark University

Hansen, A. J., \& deFries, R. (2007). Ecological Mechanisms Linking Protected Areas to Surrounding Lands. Ecological Applications, 17(4), 974-988.

Ilyas, M., Munibah, K., \& Rusdiana, O. (2014). Analisis Spasial Perubahan Penggunaan Lahan dalam Kaitannya dengan Penataan Zonasi Kawasan Taman Nasional Gunung Halimun Salak. Majalah Ilmiah Globe, 16(1), 33-42. 
Jensen, J. R. (1996). Introductory Digital Image Processing: A Remote Sensing Perspective. $2^{\text {nd }}$ Edition. Prentice-Hall, Inc.

Khoi, D. D., \& Murayama, Y. (2010). Forecasting Areas Vulnerable to Forest Conversion in the Tam Dao National Park Region, Vietnam. Remote Sens, 2(5), 1249-1272.

Lillesand, T. M., \& Kiefer, R. W. (1997). Penginderaan Jauh dan Interpretasi Citra. Yogyakarta: Gadjah Mada University Press.

Martinuzzi, S., Radeloff, V. C., Joppa, L. N., Hamilton, C. M., Helmers, D. P., Platinga, A. J., \& Lewis, D. J. (2015). Scenarios of future land use change around United States' protected areas. Biological Conservation, 184, 446-455.

Mascia, M. B., \& Pailler, S. (2011). Protected area downgrading, down-sizing, and degazettement (PADDD) and its conservation implications. Conservation Letters, 4(1), 9-20.

Mozumder, C., \& Tripathi, N. K. (2014). Geospatial Scenario Based Modelling of Urban and Agricultural Intrusions in Ramsar Wetland Deepor Beel in Northeast India using a Multi-layer Perceptron Neural Network. International Journal of Applied Earth Observation and Geoinformation, 32, 92104.

Nurman, H. (2016). Pengelolaan Penggunaan Lahan di Kawasan Taman Nasional Gunung Halimun Salak Kabupaten Lebak. Tesis. Sekolah Pascasarjana, Institut Pertanian Bogor.

Prabowo, D. P., Bachri, S., \& Wiwoho, B. S. (2017). Prediksi Perubahan Penggunaan Lahan dan Pola Berdasarkan Citra Landsat Multiwaktu dengan Land Change Modeler (LCM) Idrisi Selva 17: Studi Kasus Subdas Brantas Hulu. Jurnal Pendidikan Geografi, 22(1), 32-48.
Purbawiyatna, A., Kartodiharjo, H., Alikodra, HS., \& Prasetyo, L. B. (2012). Analisis Kebijakan Pengelolaan Hutan Rakyat untuk Mendorong Fungsi Lindung. Jurnal Pengelolaan Sumberdaya Alam dan Lingkungan, 2(1), 1-10.

Saifullah, K., Barus, B., \& Rustiadi, E. (2017). Spatial Modelling of Land Use Cover Change (LUCC) in South Tangerang City, Banten. IOP Conference Series Earth and Environmental Science, 54(1), 1-11.

Trimarwanti, T. K. E. (2014). Evaluasi Perubahan Penggunaan Lahan Kecamatan di Daerah Aliran Sungai Cisadane Kabupaten Bogor. Jurnal Pembangunan Wilayah dan Kota, 10(1), 43-58.

Wardani, D. W., Danoedoro, P., \& Susilo, B. (2016). Kajian Perubahan Penggunaan Lahan Berbasis Citra Satelit Penginderaan Jauh Resolusi Menengah dengan Metode Multi Layer Perceptron dan Markov Chain. Majalah Geografi Indonesia, 30(1), 9-18. 